\title{
Studies on biodiesel produced from Jatropha oil in Cambodia by a non- catalytic using $\mathrm{C}_{2} \mathrm{H}_{5} \mathrm{OH}$
}

\author{
- Nguyen Van Phuoc \\ Institute for Environment and Resources \\ - Chhoun Vi Thun \\ - Pham Thanh Quan \\ Hochiminh City University of Technology \\ (Manuscript Received on 07.08. 2014, Manuscript Revised 14.10, 2014)
}

\begin{abstract}
:
Different technologies are currently available for biodiesel production from various kinds of lipid containing feedstock. Among them, the alkaline-catalyzed methods are the most widely studied. However, here are several disadvantages related to biodiesel production using alkaline catalysts such as generation of wastewater, catalyst deactivation, difficulty in the separation of biodiesel from catalyst and glycerin, etc. To limit the problems mentioned above, in this study, biodiesel is produced by a non-

catalytic using $\mathrm{C}_{2} \mathrm{H}_{5} \mathrm{OH}$. The effect of experimental variables (the molar ratio ethanol/oil of 41.18:1 - 46.82:1, reaction times of 50 - 90 minutes and reaction temperatures of $275^{\circ} \mathrm{C}-295^{\circ} \mathrm{C}$ ) on the yield of biodiesel was studied. The $96 \%$ yield of Cambodia biodiesel of reaction between $\mathrm{C}_{2} \mathrm{H}_{5} \mathrm{OH}$ and Jatropha Oil at 46:1 at temperature $290^{\circ} \mathrm{C}$ at 60 minutes no using catalysts. Obtained biodiesel fuel was up to the International Standard ASTM D6751 for biodiesel fuel blend stock (B100).
\end{abstract}

Key words: Biodiesel, Jatropha oil, alcoholysis, ethanol.

\section{INTRODUCTION}

Jatropha curcas L. is a small shrub with gray bark, white sap flows when cut. Normally plants grow $4 \mathrm{~m}$ high and can reach a height of up to 5 meters in favorable conditions [2]. In Cambodia, they grow mainly and abundantly in a mountainous region of the north and central part, the littoral region from Banteaymeanchey province to Kampongthom province as traditional medicine and hedge such as: Battambong, Pursat, Kampongspeu, Sihanouk city, Kandal, Preyveng, Kampot, Kampongcham.
The oil content in seeds is $30-50 \%$ depending on varieties, soil, cultivation technique, providing sample supply of raw materials which derived from vegetation and animals.

Biodiesel is a mixture of fatty acid alkyl esters that can be produced by different techniques such as microemulsion, direct use or blending, thermal cracking (or pyrolysis), and transesterification (Boro et al., 2012). Among them, transesterification (or alcoholysis) is the most common method to produce biodiesel from 
various lipid containing feedstocks such as vegetable oils and animal fats. Recently, supercritical transesterification has been proposed as an attractive method to produce biodiesel in the absence of catalyst, which is more efficient and environmentally friendly than

\section{MATERIALS AND METHODS}

\section{Materials and Equipment}

Jatropha Curcas L., seeds are provided by Sodeco Company, Banteaymeanchey province, Cambodia. The Jatropha seeds were pressed by the Germany press machine - GTZ Organization, the power of $10 \mathrm{~W}$ to extract oil. The oil was then stored in the tank, let stand for $24 \mathrm{hrs}$ and carefully decanted. catalytic transesterification process. This paper focuses on optimizing the reaction condition for molar ratio of ethanol to oil, duration of reaction with 1 process and operation temperature in one step procedure to produce biodiesel fuel (BDF) from Jatropha oil.

The fatty acid profile of the crude oil was determined by gas chromatography, using GC MS HP - 6890, according to EN14103: 2003 standard method. Chemical composition of jatropha seed oil is shown in table 1. The study also identified the viscosity of Jatropha oil is about $34.35 \mathrm{~mm}^{2} / \mathrm{s}$, more than $7-17$ times of diesel oil 46 [1].

Table 1. Chemical composition of jatropha seed oil in Cambodia

\begin{tabular}{|c|l|l|l|l|c|}
\hline $\mathrm{N}^{0}$ & \multicolumn{1}{|c|}{$\begin{array}{c}\text { Analysis } \\
\text { Content }\end{array}$} & \multicolumn{1}{|c|}{ Method } & \multicolumn{1}{c|}{ Result } & Formula & Unit, wt\% \\
\hline \multirow{2}{*}{1} & The fat acid & AOCSCele -91 & A Palmitic (C16:0) & $\mathrm{C}_{15} \mathrm{H}_{31} \mathrm{COOH}(256)$ & 12.35 \\
& component & & A Palmitoleic (C16:1) & $\mathrm{C}_{15} \mathrm{H}_{29} \mathrm{COOH}(254)$ & 0.56 \\
& & & A Stearic $(\mathrm{C} 18: 0)$ & $\mathrm{C}_{17} \mathrm{H}_{35} \mathrm{COOH}(284)$ & 8.15 \\
& & & A Oleic (C18:1) & $\mathrm{C}_{17} \mathrm{H}_{33} \mathrm{COOH}(282)$ & 48.23 \\
& & & A Linoleic $(\mathrm{C} 18: 2)$ & $\mathrm{C}_{17} \mathrm{H}_{31} \mathrm{COOH}(280)$ & 29.9 \\
& & & A Linolenic (C18:3) & $\mathrm{C}_{17} \mathrm{H}_{29} \mathrm{COOH}(278)$ & 0.51 \\
& & & A Behenic $(\mathrm{C} 22: 0)$ & $\mathrm{C}_{21} \mathrm{H}_{39} \mathrm{COOH}(288)$ & 0.3 \\
\hline
\end{tabular}

\section{Experiments setup and reactor operation}

To achieve purpose of this study, the experiment was conducted as follows: The molar ratios of ethanol/oil in the reaction processes was $41.18: 1,42: 1,44: 1, \quad 46: 1$ and 46,82:1, the reaction times ranged of $50-90$ minutes and reaction temperatures was $275^{\circ} \mathrm{C}, 280^{\circ} \mathrm{C}, 285^{\circ} \mathrm{C}$, $290^{\circ} \mathrm{C}$ and $295^{\circ} \mathrm{C}$. The analysis method have a high accurate and repeated 3 times for each of experimental.

Operation of transesterification process: Small scale production of biodiesel was carried out using 87 gram of oil. Transesterification result of jatropha oil was investigated by changing ethanol to oil molar ratios, residence time and temperature, respectively.

After the reaction ends, product was poured into the separator and settled for 3 hours. The mixture was separated into two phases: EE pale yellow liquid above, the glycerol was the darker colored liquid on the bottom. The light phase was extracted, neutralized acetic acid and settle for 1 hour. The product after settling was cleaned in warm water and settle for 30 minutes, then dried by stirring with heat at $120^{\circ} \mathrm{C}$.

\section{Analysis}

Thin layer chromatography 
The conversion of oil to BDF was monitored by thin layer chromatography (TLC) using silicagel 60 F254 (Merk) plates.

The solvents consisting of chloroform to petroleum ether varied continuously from 1:10 to 10:10 with the total amount of the eluent at 20 $\mathrm{ml}$. The optimal ratio of 1:2 was used as preliminary analysis of oil composition.

\section{BDF from jatropha oil in Cambodia}

Composition of methyl esters were identified by high pressure liquid chromatography (HPLC) according to the following analysis process: Aliquots $(1 \mathrm{ml})$ were taken from the outlet at each two volumes replacement and left to stand for 2 hrs for products separation. An accurate amount of $100 \mathrm{mg}$ from the upper layer was diluted in the mobile phase to a concentration of $3 \%(\mathrm{w} / \mathrm{w})$ and analyzed for the concentration of triglycerides, diglycerides, monoglycerides, and FAEEs by reversed phase chromatography. The composition of the transesterification reaction products was determined by HPLC using a Shimadzu chromatograph, consisting of a Model LC - 10A HPLC pump and a Model RID 10A refractive index detector.

The LC column was a Cadenza CD - C18 polymer - based column, $25 \mathrm{~cm}$ x $3.0 \mathrm{~mm}$ with 4 $\mu \mathrm{m}$ diameter particle size silica.

\section{RESULTS AND DISCUSSION}

Effect of reaction conditions on the ethyl esters yield

Small scale production of biodiesel was carried out using 87 gram of oil. Transesterification result of jatropha oil was investigated by changing ethanol to oil molar ratio, residence time and temperature, respectively.

From the experimental results, after building the regression equation and eliminating the
In all cases, the mobile phase was an acetone/acetonitrile mixture, 70:30, with a flow rate of $0.4 \mathrm{ml} / \mathrm{min}$ and a loop of $20 \mu \mathrm{l}$. By using standard grade reagent calibration curves were generated using as internal standard nhexadecane.

The molar concentrations of triglycerides and ethyl esters (EE) were evaluated from the areas of relevant peaks, according to the following formula: $\mathrm{C}_{\mathrm{TG}}=\left(\mathrm{a}^{*} \mathrm{~A}_{\mathrm{TG}} / \mathrm{A}_{\mathrm{IS}}+\mathrm{b}\right)^{*} \mathrm{C}_{\mathrm{IS}}+$ b) ${ }^{*} \mathrm{C}_{\text {IS }}^{*} 100 / \mathrm{M}$.

Where a is the slope of calibration function, $\mathrm{b}$ is the intercept of calibration function, $\mathrm{C}_{\mathrm{TG}}$ is the weight percentage of triglycerides in the sample, $\mathrm{A}_{\mathrm{TG}}$ is the sum of peak area of individual triglycerides, $A_{I S}$ is the peak area of internal sample, weight; and $\mathrm{M}$ is weight of sample. The data presented are averages of three replicates of determination [5].

The Biodiesel performance $\mathrm{H}(\%)$ according to the following formula:

$$
H(\%)=\frac{m_{\text {biodiesel }} \times C}{\frac{3 m}{M} \times M_{F A E E}} \times 100 \%
$$

Where $\mathrm{C}$ is concentrations of ethyl esters, $\mathrm{m}_{\text {biodiesel }}$ is weight of biodiesel, $\mathrm{m}$ is weight of Jatropha oil, $\mathrm{M}$ and $\mathrm{M}_{\mathrm{FAEE}}$ is the average molecular weight of Jatropha oil and FAEE.

inconsistent regression coefficient - the coefficient $\mathrm{f}<\mathrm{f}(0,05 ; 3)=2.35$, and checking the fit of the model by Fisher standard ( $\mathrm{F}$ model $=$ $1.86<$ F table $(0,05 ; 5 ; 3)=9.01)$.

Mathematical model describing the researching process as follows:

The encode equation: $\mathrm{Y}=93.11+0.81 \mathrm{X}_{1}+$ $1.47 \mathrm{X}_{2}+0,39 \mathrm{X}_{1}^{2}$

\section{Trang 104}


The real equation: $\mathrm{Y}=223.63-8.24 \mathrm{Z}_{1}+$ $0.15 \mathrm{Z}_{2}+0.098 \mathrm{Z}_{1}^{2}$

The regression equation shows the performance of biodiesel is affected by the proportion level 1 of reaction temperature, level 1 and level 2 of ethanol/oil. With the molar ratio ethanol/oil from $42: 1$ to $46: 1$, the higher performance of biodiesel catalysis when higher concentrations. In the same molar ratio ethanol/oil, biodiesel performance is directly proportional to the reaction temperature. From the regression equation above, optimal conditions to achieve the highest performance biodiesel (96\%) as follows: the ratios of ethanol/oil 46:01, reaction time of $60 \mathrm{~min}$ and reaction temperature of $290^{\circ} \mathrm{C}$.

Table 2. Effect of reaction yield

\begin{tabular}{|c|c|c|c|c|c|c|c|}
\hline $\mathrm{N}^{0}$ & $\mathrm{X}_{1}$ & $\mathrm{X}_{2}$ & $\mathrm{X}_{3}$ & $\begin{array}{c}\mathrm{Z}_{1}, \\
\mathrm{CH}_{3} \mathrm{OH} / \mathrm{Oil}\end{array}$ & $\mathrm{Z}_{2},{ }^{0} \mathrm{C}$ & $\begin{array}{c}\mathrm{Z}_{3}, \\
\text { minutes }\end{array}$ & $\begin{array}{c}\text { Biodiesel } \\
\text { Yield, } \%\end{array}$ \\
\hline 1 & 1 & 1 & 1 & $46: 1$ & 290 & 80 & 96 \\
\hline 2 & -1 & 1 & 1 & $42: 1$ & 290 & 80 & 95 \\
\hline 3 & 1 & -1 & 1 & $46: 1$ & 280 & 80 & 93 \\
\hline 4 & -1 & -1 & 1 & $42: 1$ & 280 & 80 & 92 \\
\hline 5 & 1 & 1 & -1 & $46: 1$ & 290 & 60 & 96 \\
\hline 6 & -1 & 1 & -1 & $42: 1$ & 290 & 60 & 95 \\
\hline 7 & 1 & -1 & -1 & $46: 1$ & 280 & 60 & 93 \\
\hline 8 & -1 & -1 & -1 & $42: 1$ & 280 & 60 & 92 \\
\hline 9 & 1.41 & 0 & 0 & $46.82: 1$ & 285 & 70 & 95 \\
\hline 10 & -1.41 & 0 & 0 & $41.18: 1$ & 285 & 70 & 91 \\
\hline 11 & 0 & 1.41 & 0 & $44: 1$ & 295 & 70 & 94 \\
\hline 12 & 0 & -1.41 & 0 & $44: 1$ & 275 & 70 & 90 \\
\hline 13 & 0 & 0 & 1.41 & $44: 1$ & 285 & 90 & 93 \\
\hline 14 & 0 & 0 & -1.41 & $44: 1$ & 285 & 50 & 92 \\
\hline 15 & 0 & 0 & 0 & $44: 1$ & 285 & 70 & 94 \\
\hline 16 & 0 & 0 & 0 & $44: 1$ & 285 & 70 & 93 \\
\hline
\end{tabular}

Table 3. The results of analysis of factors affecting coding for regression models

\begin{tabular}{|l|r|r|r|r|r|}
\hline \multicolumn{1}{|c|}{ Factors } & \multicolumn{1}{c|}{$\begin{array}{l}\text { Sum of } \\
\text { squares }\end{array}$} & \multicolumn{1}{c|}{ df } & \multicolumn{1}{c|}{$\begin{array}{l}\text { Mean of } \\
\text { squares }\end{array}$} & F value & Coefficient estimate \\
\hline A-X1 & 7.76 & 1 & 7.76 & 4.92 & +92.69 \\
\hline B-X2 & 25.98 & 1 & 25.98 & 16.48 & +1.13 \\
\hline C-X3 & 0.17 & 1 & 0.17 & 0.11 & +2.08 \\
\hline AB & $7.105 \mathrm{E}-015$ & 1 & $7.105 \mathrm{E}-015$ & $4.508 \mathrm{E}-015$ & +0.17 \\
\hline $\mathrm{AC}$ & $7.105 \mathrm{E}-015$ & 1 & $7.105 \mathrm{E}-015$ & $4.508 \mathrm{E}-015$ & $-2.557 \mathrm{E}-016$ \\
\hline $\mathrm{BC}$ & 0.000 & 1 & 0.000 & 0.000 & $-1.120 \mathrm{E}-015$ \\
\hline $\mathrm{A}^{\wedge} 2$ & 2.04 & 1 & 2.04 & 1.30 & $-4.041 \mathrm{E}-018$ \\
\hline $\mathrm{B}^{\wedge} 2$ & 0.018 & 1 & 0.018 & 0.011 & +1.10 \\
\hline
\end{tabular}




\begin{tabular}{|l|r|r|r|r|r|}
\hline \multicolumn{1}{|c|}{ Factors } & \multicolumn{1}{|c|}{$\begin{array}{c}\text { Sum of } \\
\text { squares }\end{array}$} & \multicolumn{1}{c|}{ df } & \multicolumn{1}{c|}{$\begin{array}{c}\text { Mean of } \\
\text { squares }\end{array}$} & F value & Coefficient estimate \\
\hline $\mathrm{C}^{\wedge} 2$ & 0.61 & 1 & 0.61 & 0.39 & +0.10 \\
\hline Residual & 9.46 & 6 & 1.58 & & \\
\hline
\end{tabular}

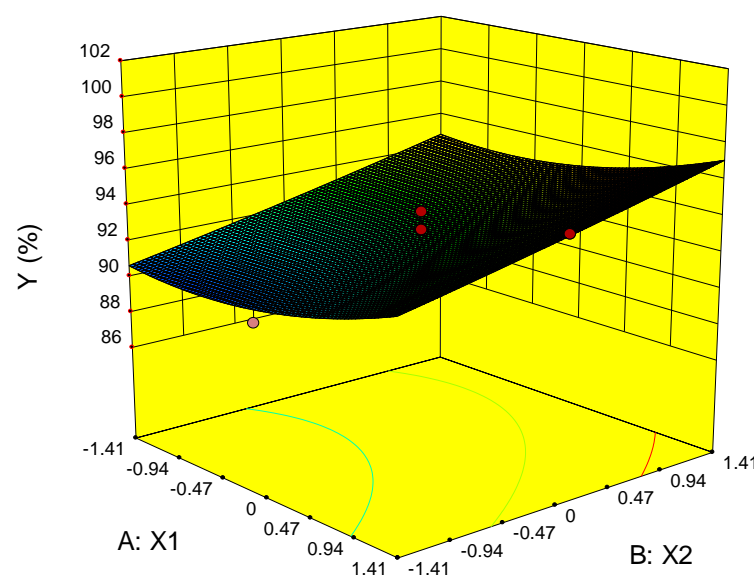

Figure 1. The influence of factors on the performance of biodiesel

The properties of jatropha biodiesel (B100) from Jatropha oil.

The properties of jatropha biodiesel (B100) is presented in Table 4. From this table, it can be

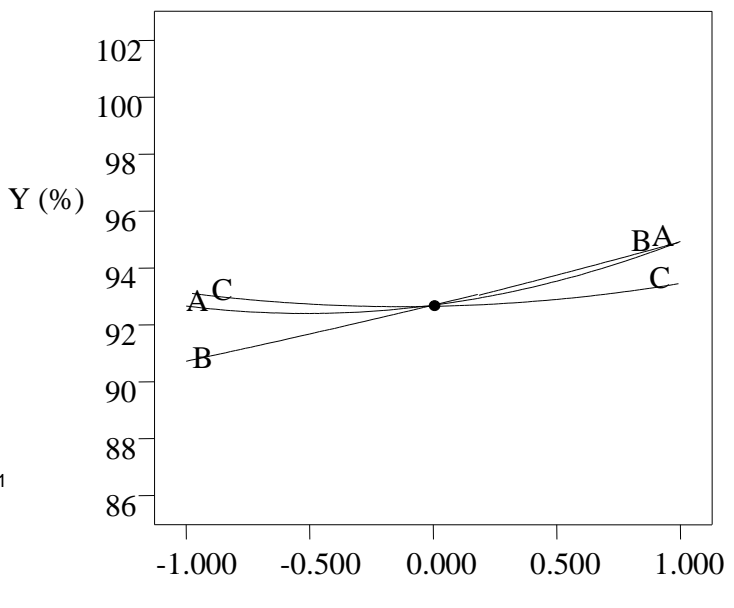

Model performance
Figure 2. Actual biodiesel performance compared with the model

seen that, all properties of biodiesel fuel from Jatropha oil (i.e. flash point, Catani number, acid number, cloud point, and kinematic viscosity at $40^{\circ} \mathrm{C}$ ) are in conformance with ASTM D6751 standard.

Table 4. The properties of jatropha biodiesel (B100) in Cambodia [7]

\begin{tabular}{|c|l|c|c|c|c|c|c|}
\hline $\mathrm{N}^{0}$ & Contents & Units & $\begin{array}{c}\text { Method } \\
\text { ASTM }\end{array}$ & $\begin{array}{c}\text { USA } \\
\text { D6751- } \\
12\end{array}$ & $\begin{array}{c}\text { Cambodia } \\
\text { Jatropha } \\
\text { biodiesel } \\
(\mathrm{B} 100)\end{array}$ & $\begin{array}{c}\text { Vietnam } \\
\text { biodiesel } \\
(\mathrm{B} 100)\end{array}$ & $\begin{array}{c}\text { India } \\
\text { Jatropha } \\
\text { biodiesel } \\
(\mathrm{B} 100)\end{array}$ \\
\hline 1 & Density at $15^{\circ} \mathrm{C}$ & $\mathrm{kg} / \mathrm{dm}^{3}$ & $\mathrm{D} 1298$ & $0.8-0.9$ & 0.85 & 0.8853 & 0.88 \\
\hline 2 & Kinematic viscosity at $40^{\circ} \mathrm{C}$ & $\mathrm{mm}^{2} / \mathrm{s}$ & $\mathrm{D} 445$ & $1.9-6.0$ & 4 & 5.072 & 4.84 \\
\hline 3 & Acid number, max & $\mathrm{mg} \mathrm{KOH/g}$ & $\mathrm{D} 664$ & 0.5 & 0.4 & No data & 0.24 \\
\hline 4 & Cetane number, min & - & $\mathrm{D} 613$ & 47 & 49 & 48.1 & 51.6 \\
\hline 5 & Copper strip corrosion at 3 & - & $\mathrm{D} 130$ & $\mathrm{~N}^{0} 3$ & $\mathrm{~N}^{0} 1 \mathrm{a}$ & $\mathrm{N}^{0} 1 \mathrm{a}$ & No data \\
\hline 6 & Carbon residue, max & $\%$ mass & $\mathrm{D} 4530$ & 0.05 & 0.00 & 2.18 & 0.025 \\
\hline 7 & Cloud point & ${ }^{0} \mathrm{C}$ & $\mathrm{D} 2500$ & report & -7 & +3 & -6 \\
\hline
\end{tabular}

\section{Trang 106}




\begin{tabular}{|c|l|c|c|c|c|c|c|}
\hline $\mathrm{N}^{0}$ & Contents & Units & $\begin{array}{c}\text { Method } \\
\text { ASTM }\end{array}$ & $\begin{array}{c}\text { USA } \\
\text { D6751- } \\
12\end{array}$ & $\begin{array}{c}\text { Cambodia } \\
\text { Jatropha } \\
\text { biodiesel } \\
(\mathrm{B} 100)\end{array}$ & $\begin{array}{c}\text { Vietnam } \\
\text { biodiesel } \\
(\mathrm{B} 100)\end{array}$ & $\begin{array}{c}\text { India } \\
\text { Jatropha } \\
\text { biodiesel } \\
(\mathrm{B} 100)\end{array}$ \\
\hline 8 & $\begin{array}{l}\text { Flash point at closed cup, } \\
\text { min }\end{array}$ & ${ }^{0} \mathrm{C}$ & $\mathrm{D} 93$ & 93 & 200 & $>148$ & 162 \\
\hline 9 & Calorific value, $\min$ & $\mathrm{Mj} / \mathrm{kg}$, & $\mathrm{D} 4809$ & 35 & 41.15 & 39.7 & 37.2 \\
\hline
\end{tabular}

\section{CONCLUSIONS}

The production of biodiesel from crude jatropha oil containing via supercritical ethanol transesterification was reported in this work. It can be concluded that:

+ Performance of biodiesel is affected by the proportion level 1 of reaction temperature, level 1 and level 2 of ethanol/Oil. In there, molar ratio of ethanol/oil is most influential.

+ Optimal conditions to achieve the highest performance biodiesel (96\%) as follows: the molar ratio of ethanol/oil 46:01, reaction time of $60 \mathrm{~min}$ and reaction temperature of $290^{\circ} \mathrm{C}$.

$+\quad$ The Cambodia biodiesel is high quality and can be used for the diesel machines as water pumping machine, ferry, ship, tractors, lorry, buses, motor cars, stationery, electrical machine, rice pressing machines... the quality of the Cambodia Biodiesel is alright in Cambodia Standard and International Standard as TCVN BDF 100, EN14214 and USA D6751.

\section{Nghiên cứu sản xuất biodiesel từ dầu Jatropha bằng $\mathrm{C}_{2} \mathrm{H}_{5} \mathrm{OH}$ không sử dụng xúc tác}

\section{- Nguyễn Văn Phước}

Viện Môi trường và Tài nguyên

\section{- Chhoun Vi Thun}

\section{- Phạm Thành Quân}

Trường Đại học Bách Khoa, ĐHQG-HCM

\section{TÓM TÁT:}

Hiện nay có nhiều công nghệ khác nhau được ứng dụng để sản xuất dầu diesel sinh học từ các nguyên liệu có chứa lipid. Trong số đó, phương pháp xúc tác kiềm được nghiên cứu rộng rãi nhất. Tuy nhiên, phương pháp này có một số nhược điểm nhu: phát sinh nước thải, chất xúc tác bị vô hiệu hóa,

hoặc khó khăn trong việc tách dầu diesel sinh học khỏi hỗn hợp chất xúc tác và glycerin,... Để hạn chế các vấn đề nêu trên, trong nghiên cứu này, biodiesel được điều chế bằng phương pháp không sử dụng xúc tác dùng alcohol, cu thể là $\mathrm{C}_{2} \mathrm{H}_{5} \mathrm{OH}$. Ảnh hưởng của các yếu tố thí nghiêm anhe 
hưởng đến sản lượng biodiesel đã được nghiên cứu, nhu: tỷ lệ phân tử etanol/dầu thay đổi từ 41,18:1 - 46,82:1, thời gian phản ưng từ 50 - 90 phút, và nhiệt độ phản ứng thay đổi từ $275-295^{\circ} \mathrm{C}$. Sản lượng biodiesel tối ưu đạt được 96\% trong điều kiện: tỷ lệ phản ứng giữa $\mathrm{C}_{2} \mathrm{H}_{5} \mathrm{OH}$ và dầu Jatropha là 46:1 ở nhiệt độ $290^{\circ} \mathrm{C}$ trong thời gian 60 phút, không sử dụng chất xúc tác. Sản phẩm thu được bảo đảm các Tiêu chuẩn quốc tế ASTM D6751 cho nhiên liệu diesel sinh học gốc (B100).

Key words: Biodiesel, dầu Jatropha, siêu tới hạn, ethanol

\section{REFERENCES}

[1]. Đặng Tiến Hòa, Bùi Hải Triều, Kết quả nghiên cứu bước đầu về khả năng sử dụng dầu Jatropha cho động cơ Diesel, Tạp chí Khoa học và Phát triển 2011, Tập 9, số 1, $110-119$.

[2]. Le Viet Hai, Nguyen Thanh Tien, Nguyen Thi Phuong Thoa, Nguyen Mong Hoang, Nguyen $\mathrm{Nu}$ Hoang Duyen, Ultrasonically process for biodiesel synthesis from Jatropha carcass seed oil, Proceedings of the 2009 International Forum On Strategic Techologies (IFOST-2009), Ho Chi Minh City, Vietnam, October 21-23, 2009, pp. 4046.

[3]. Nguyen Mong Hoang, Le Viet Hai, Nguyen Thi Phuong Thoa, Producing biodiesel from Jatropha carcass seed oil by thermal-stirring method with alkali catalyst $\mathrm{NaOH}$, Proceedings of the 2009 International Forum On Strategic Technologies (IFOST2009), Ho Chi Minh City, Vietnam, October 21-23, 2009, pp. 56-60.

[4]. Yasuaki Maeda, Le Tu Thanh, Kenji Okitsu, Norimichi Takenaka, Hiroshi Bandow, Luu
Van Boi, Nguyen Thi Phuong Thoa, Nguyen Thi Phuong Thao, New Green Technology for the Biodiesel Fuel Production from Waste Fish and Jatropha Carcass Oils in Vietnam (2009), Proceedings of the 2009 International Forum On Strategic Technologies (IFOST-2009), Ho Chi Minh City, Vietnam, October 21-23, 2009.

[5]. Nguyen $\mathrm{Nu}$ Hoang Duyen, Nguyen Thi Phuong Thoa, Le Viet Hai, Synthesis of ethyl ester from jatropha seed oil for biodiesel fuel (2010), Journal of chemistry 48 (4A) 742-747.

[6]. Nguyen Thi Giang Huong, Cao thi Thu Hong, Ton Nu Thanh Phuong, Le Viet Hai, Nguyen Thi Phuong Thoa, One step synthesis of biodiesel from jatropha carcass seed oil by thermo chemical method (2010), Journal of chemistry 48 (4C) 182-187.

[7]. Paltil V. and Singh K., Oil gloom to oil boom, jatropha carcass a promising agro forestry crop, Shree Offset Press, Nashik, India, 1991. 